\title{
THE EMPLOYMENT EFFECTS OF RECENT MINIMUM WAGE INCREASES: EVIDENCE FROM A PRE-SPECIFIED RESEARCH DESIGN
}

David Neumark

Working Paper 7171

http://www.nber.org/papers/w7171

NATIONAL BUREAU OF ECONOMIC RESEARCH

1050 Massachusetts Avenue

Cambridge, MA 02138

June 1999

I am grateful to David Levine, Lowell Taylor, William Wascher, and anonymous referees for helpful comments, and to Yuri Soares for outstanding research assistance. All opinions expressed are those of the authors and not those of the National Bureau of Economic Research.

(C) 1999 by David Neumark. All rights reserved. Short sections of text, not to exceed two paragraphs, may be quoted without explicit permission provided that full credit, including $($ notice, is given to the source. 
The Employment Effects of

Recent Minimum Wage Increases:

Evidence from a Pre-specified Research Design

David Neumark

NBER Working Paper No. 7171

June 1999

JEL No. J38

\section{ABSTRACT}

This paper presents evidence on the employment effects of recent minimum wage increases from a pre-specified research design that entailed committing to a detailed set of statistical analyses prior to "going to" the data. Despite the limited data to which the pre-specified research design can be applied, evidence of disemployment effects of minimum wages is often found where we would most expect it-for younger, less-skilled workers.

David Neumark

Department of Economics

Michigan State University

East Lansing, MI 48824

and NBER

neumarkd@pilot.msu.edu 


\section{$\underline{\text { I. Introduction }}$}

Research on minimum wages conducted over the 1990s has utilized a wide variety of data sets and empirical approaches. Table 1 summarizes the elasticities of employment with respect to the minimum wage from a subset of these studies that use relatively common regression or difference-in-difference procedures to estimate minimum wage effects. ${ }^{1}$ In cases where a range of estimates is reported, I have tried to extract those estimates that the authors indicate are preferred.

Table 1 illustrates two points. First, there is a fairly wide range of estimated employment effects of minimum wages, ranging from large positive to moderately large negative elasticities. This variation in estimated minimum wage effects may be attributable to differences in data sources, empirical approaches, and unbiased (although partially subjective) specification analyses and decisions made by the various authors.

Second, Table 1 also suggests that multiple studies by particular authors tend to be associated with certain qualitative findings, and I conjecture that this evidence would be even more apparent from a fuller consideration of all of the published research on minimum wages. This raises the question of whether authors may have made specification decisions in the course of their research that tended to systematically push the results in one direction or another, perhaps driven by consistency of the empirical results with their priors, giving rise to "author effects" in the published findings. ${ }^{2}$

Given this latter possibility, the goal of this symposium, as I understand it, was to attempt to obtain estimates of employment effects of minimum wages that are free from any bias that might be

${ }^{1}$ In contrast, for example, Neumark and Wascher (1994a) use a disequilibrium model of the low-wage labor market to estimate minimum wage effects.

${ }^{2}$ In fact, Card and Krueger (1995) have argued that evidence from a meta-analysis of earlier timeseries minimum wage studies suggests that such biased specification search is likely partly responsible for negative estimates of minimum wage effects reported in that literature, although Neumark and Wascher (1998b) present evidence to the contrary. 
introduced via the process of specification search. This was to be accomplished by proposing that various authors involved in the minimum wage debate (1) pre-specify a research design that would use data not yet available, (2) subject that research design to peer review before any data analysis was performed, and (3) carry out the pre-specified analysis when the data became available. The evidence resulting from such pre-specified research designs should provide estimates of the employment effects of minimum wages that are free of author effects, by eliminating specification search.

Although for reasons discussed below I do not believe that this new evidence is likely to settle the debate--aside from the fact that other prominent researchers in the minimum wage debate declined to participate--I do believe that it makes a useful contribution. Moreover, I want to clarify at the outset that I have no reason to believe that any of the researchers involved in this debate were consciously trying to manipulate the results. The question, however, is whether in the rather complicated, drawn-out, and partially ad hoc process of sifting through empirical results from a variety of specifications to settle on the "robust" relationships in the data--which is my view of the nature of much empirical research, my own included--researchers may nonetheless have tended to make decisions that had a systematic influence on the signs or magnitudes of estimated minimum wage effects.

As an example, one specification choice in Neumark and Wascher (1992) that tends to result in stronger negative estimates of minimum wage effects is the inclusion of a one-year lag of the minimum wage variable. In the data analyzed in that paper, the estimated coefficient of the lagged variable is generally significant, and leads to stronger estimated disemployment effects of minimum wages. We might expect that there are robust relationships in data sets that would appear in a variety of time periods and contexts, and would therefore likely be uncovered by most researchers engaged in empirical analysis. On the other hand, there may be relationships that randomly appear in 
a particular data set, and those that are more consistent with a researcher's priors may be more likely to be chosen, emphasized, or perhaps even noticed. The commitment to a pre-specified research design is intended to eliminate the influence of the latter type of phenomenon on reported results. If the larger lagged effects represent a robust and replicable empirical relationship, then a pre-specified research design using the types of specifications chosen in earlier analyses should reveal the same lagged effects. In the case of biased specification search, however, these same effects are less likely to reappear.

Nonetheless, there are some limitations to what we can learn from pre-specified research designs. It is possible that a robust relationship that generally holds will nonetheless not appear in the particular data set I analyze in this paper, because of random correlation between the minimum wage and other included or excluded variables. By the same token, researchers analyzing past data sets may have been completely objective, yet nonetheless chosen a specification that does not capture a robust relationship that appears in other data sets. The fact that we cannot distinguish between these two scenarios and biased specification search limits to some extent what we can learn from pre-specified research designs. In particular, while we should obtain estimates that are free of author effects, we probably cannot convincingly test for author effects (in the sense of biased specification search) in past studies. In addition, a pre-specified research design by definition throws out previously-available data, which may seriously impede the search for robust empirical relationships in the data. On the other hand, I think that this approach adds valuable evidence to the minimum wage debate, and that, more generally, further development of this type of research strategy may yield additional insights into how to obtain more convincing evidence--in this and other contexts--that is free of biased specification search.

The following section (Section II) describes my pre-specified research design. Section II was the "core" of the proposal that was submitted to this journal for refereeing prior to looking at the 
data used in the study. In addition, the original submission included this introduction (Section I), as well as Tables 1 and 2. The Introduction was included as part of the original submission in order to present my a priori view of the nature of evidence from a pre-specified research design applied to the employment effects of minimum wages; clearly it was important to avoid the possibility that any reservations regarding this evidence were raised in response to results obtained from the empirical analysis. There have been no changes from the original research design (in Section II) submitted to the journal other than those based on suggestions from the referees, which were received and responded to prior to any downloading or analysis of the data. Other than that, there were only minor editorial changes or additions of clarifying or updated text to Sections I and II. What has been added to the final paper, then, is simply a description of the results from the pre-specified research design (Section III), and a summary of the findings and concluding thoughts (Section IV). ${ }^{3}$

\section{The Pre-specified Research Design}

The study focuses primarily on the increases in the federal minimum wage in October 1996 and September 1997, and, for reasons explained below, uses the October, November, and December CPS files. The files that are used to test for minimum wage effects are for October-December of 1995, 1996, 1997, and 1998. The October-December 1995 files to a large extent provide the baseline from which employment changes are measured, while the 1996-1998 files are used to measure employment changes subsequent to increases in the federal and some state minimum wages. Communications with the U.S. Census Bureau in April of 1997--soon after I was invited to

${ }^{3}$ Sections I and II of this paper were originally written in May 1997 and revised in May 1998. I will supply readers with copies of the original and revised pre-specified research designs upon request. A potential problem with pre-specified research designs is that there may be issues regarding variable definitions, sample restrictions, etc., which are omitted or incorrectly treated in the design stage, yet about which decisions have to be made when doing the empirical analysis. The hope, of course, is that any such issues are minor. In the present paper, virtually no such issues arose, probably in large part because the CPS files are relatively familiar and uncomplicated. 
participate in this symposium--indicated that the October 1996 file would be available to the public at the end of May 1997. To ensure that I could not look at any data measuring employment changes prior to writing up the research design, I completed this design and submitted it to the journal before the end of May 1997. I also assure readers that I did not examine any published data by state prior to writing up this research design.

The CPS data are used to define the following variables, used in many previous studies of minimum wage effects on employment. The dependent variables that will be examined are employment-to-population ratios (E), mainly for teenagers (aged 16-19) and young adults (aged 1624), but with some subgroups also receiving attention. Reasons for looking at these groups are discussed below. Employment will be based on the employment status recode. The prime-age (2564) male unemployment rate (U) in the state will be used to control for aggregate economic activity, and the proportion of 16-19 or 16-24 year-olds in the working age (16-64) population (denoted P), will be used to control for supply variation.

The analysis will make use of two alternative minimum wage variables. The first, similar to that used in Neumark and Wascher's work, is the ratio of the higher of the federal or state minimum wage to the average wage of workers aged 16-64 in the state (RMW). ${ }^{4}$ The second, similar to that used in Card's work (1992a), is the fraction of teens or young adults in year $\mathrm{t}-1$ that earn less than the minimum wage prevailing in year $\mathrm{t}(\mathrm{FB}) .^{5}$ These measures capture information on not only the

${ }^{4}$ Given that the sample period includes only years of very high coverage, no adjustment is made for variation in coverage across states or years.

${ }^{5} \mathrm{FB}$ is defined based on employment in the previous rather than the current year to avoid the influence of potential employment effects of minimum wage increases, and general endogeneity between employment and wages. As in Card (1992a), straight-time wages (excluding tips and commissions) are used to define FB, and are approximated by using a reported hourly wage, as opposed to usual weekly earnings/usual weekly hours, whenever the former is reported. (Additional information on tips and commissions is available beginning with the redesigned CPS in 1994, but Card's method is used both to be consistent with his methods, and because 1993 data are required as well to construct one of the lagged minimum wage variables used in the specifications described below.) 
level of the minimum but how far up the minimum wage cuts into the overall wage distribution. The minimum wage variables can be constructed only using the Outgoing Rotation Group (ORG) files of the CPS, which contain wage information. ${ }^{6}$

To obtain accurate estimates, these variables will be constructed as state-level means pooling across the three months for each year. Using October-December files is convenient because for each year in the sample period there were no state-level minimum wage increases during the period covered by these files, so we can get a "clean" estimate of labor market conditions before and after the various increases. ${ }^{7}$

Using these data, the analysis begins with estimates of the following equations:

$$
E_{i t}=\alpha+R_{i t} \beta+R_{i t} W_{i t-1} \beta^{\prime}+X_{i t} \gamma+Y_{t} \theta+S_{i} \psi+\epsilon_{i t},
$$

and

$$
\mathrm{E}_{\mathrm{it}}=\alpha+\mathrm{FB}_{\mathrm{it}} \beta+\mathrm{FB}_{\mathrm{it}-1} \beta^{\prime}+\mathrm{X}_{\mathrm{it}} \gamma+\mathrm{Y}_{\mathrm{t}} \theta+\mathrm{S}_{\mathrm{i}} \psi+\epsilon_{\mathrm{it}},
$$

where $\mathrm{X}$ includes the control variables $\mathrm{U}$ and $\mathrm{P}$, $\mathrm{i}$ indexes states, and $\mathrm{t}$ indexes years. The equations are estimated for both teenagers (aged 16-19) and young adults (aged 16-24). $\mathrm{Y}_{\mathrm{t}}$ is a set of year dummy variables that control for aggregate influences on teen or young adult employment, while $S_{t}$ is a set of state dummy variables to control for persistent differences across states in the employment of younger workers. The lagged effects are included based on earlier evidence in Neumark and Wascher (1992 and 1994b) that the stronger effect of minimum wages on youth employment occurs

${ }^{6}$ The analysis will explore whether the results are sensitive to using only the ORG files to construct the other variables.

${ }^{7}$ Although the 1996 federal increase became effective on October 1, the CPS covers the week including the 12 th of the month. 
with a lag of approximately one year. ${ }^{8,9}$ However, because of differences in the timing of minimum wage increases and the measurement of employment rates (and other controls), we would not necessarily expect the relative magnitudes of the contemporaneous and lagged effects to be the same as in the earlier research.

Of course, the estimation with state dummy variables is equivalent to forming the deviations about the state means, e.g., $\Delta \mathrm{E}_{\mathrm{it}}=\mathrm{E}_{\mathrm{it}}-\mathrm{E}_{\mathrm{i}}$. Note that the first-differenced form of FB parallels Card's (1992a) fraction-affected variable, since $\mathrm{FB}_{\mathrm{it}}-\mathrm{FB}_{\mathrm{it}-1}$ is close to the fraction of workers with wages between the year $\mathrm{t}-1$ and year $\mathrm{t}$ minimum wage, as of year $\mathrm{t}-1$. A similar interpretation applies to the within-group difference; observations with a high value of $\mathrm{FB}_{\mathrm{it}}-\mathrm{FB}_{\mathrm{i}}$, are those in which the current minimum wage is higher than the wages previously earned by a high fraction of workers. ${ }^{10}$

The changes in federal and state minimum wages over the sample period are documented in Table 2. The top rows list any states that had a minimum wage above the federal level at any time during the period covered by the data, while the bottom row lists the federal minimum wage. As the last four columns show, aside from direct increases in state minimum wages above the federal level, variation in state minimum wages also generates variation across states within a year in changes in the binding minimum wage in a state, stemming from increases in the federal minimum. In particular, in states with minimum wages set higher than the new federal level, federal minimum wage increases

${ }^{8}$ Note that because I did not yet have the October 1996 data at the time of writing the research design, I did not have information even on the contemporaneous effect of the federal minimum wage increase on, for example, changes in employment rates from October 1995 to October 1996.

${ }^{9}$ For the most-detailed analysis of this issue to date (for Canada), see Baker, et al. (1999).

${ }^{10}$ Neumark and Wascher (1994b) criticize using the fraction affected variable over a long panel, because it fails to account for the erosion of the minimum wage due to overall wage inflation. However, this study considers a short period, and one with moderate to low wage inflation, so this problem seems unlikely to be very important. 
have no effect, and in states with minimum wages above the old but below the new federal level, federal minimum wage increases have smaller effects. However, there is perhaps less variation than we would like, which makes this a less than ideal time period to study minimum wage effects. Of the 50 states and the District of Columbia, the minimum wage rose by $\$ .50$ (the federal increase) in all but seven of them from 1995 to 1996 . From 1996 to 1997 the minimum wage increase differed from the federal increase for only six states, and in two of these six the increase only differed by $\$ .10$. There were minimum wage increases in 1998 in California and Oregon, although it will not be possible to obtain information on the lagged effects of these increases given the sample period. Finally, Alaska, Hawaii, and other small New England states provide 7 of the 16 observations with differential minimum wage changes. This contrasts, for example, with Card's (1992a) study, in which the minimum wage increase differed from the federal increase for 16 out of 51 observations. However, the proportion of observations with changes differing from the federal level was lower in the data used by Neumark and Wascher (1992), which extended back to the early 1970s.

Because the minimum wage variables in equations (1) and (2) are not simply the levels of the minimum wage, even with year effects included, and in the absence of state-level variation in minimum wages, the increases in the federal minimum wage provide some identifying information. Nonetheless, state-level variation in minimum wages is widely viewed as essential to identifying minimum wage effects, since without it changes in the minimum wage variables (RMW or FB) may stem largely from sources unrelated to minimum wage changes, but possibly correlated with changes in the wage distribution and the dependent variable. The alternative of excluding year effects to exploit more fully the variation in the federal minimum wage is likely to be unattractive, since there are most likely cyclical or trend effects on youth employment rates. It is possible, however, that the control variables in equations (1) and (2), as well as others discussed below, capture these effects; Hausman tests will be used to examine this issue (for state effects as well). 
The analysis using equations (1) and (2) assumes that, in the absence of minimum wage increases, movements in employment of young workers would be similar across states, and hence captured in the year dummy variables $Y_{t}$. Work by Deere, et al. (1995) cautions against this assumption. In particular, they find that the increases in the federal minimum wage in 1990 and 1991 tended to reduce employment of low-skill groups more than high-skill groups, although this pattern was not evident in a comparison of employment effects for low-wage states and high-wage states. In particular, employment growth of higher-skill workers was stronger in the lowest-wage states where the federal minimum wage increase would have had the most impact on wages. Assuming similar trends in employment of low-skill workers (in the absence of minimum wage effects), this may have obscured the minimum wage effect. To some extent, the inclusion of the unemployment rate of prime-age males should help control for this. However, employment rates and unemployment rates may not be that tightly linked, so controls will also be added for the employment rates of prime-age adults with more than a high school education for the same period in which the dependent variable is measured; this is the same group that Deere, et al. (1995) use to examine overall employment trends, reasoning that this group is unlikely to be influenced by the minimum wage. Thus, augmented versions of equations (1) and (2) of the form

$$
\mathrm{E}_{\mathrm{it}}=\alpha+\mathrm{RMW}_{\mathrm{it}} \beta+\mathrm{RMW}_{\mathrm{it}-1} \beta^{\prime}+\mathrm{X}_{\mathrm{it}} \gamma+\mathrm{ESA}_{\mathrm{it}} \lambda+\mathrm{Y}_{\mathrm{t}} \theta+\mathrm{S}_{\mathrm{i}} \psi+\epsilon_{\mathrm{it}}
$$

and

$$
\mathrm{E}_{\mathrm{it}}=\alpha+\mathrm{FB}_{\mathrm{it}} \beta+\mathrm{FB}_{\mathrm{it}-1} \beta^{\prime}+\mathrm{X}_{\mathrm{it}} \gamma+\mathrm{ESA}_{\mathrm{it}} \lambda+\mathrm{Y}_{\mathrm{t}} \theta+\mathrm{S}_{\mathrm{i}} \psi+\epsilon_{\mathrm{it}},
$$

will also be estimated, where ESA is the employment rate of more-skilled prime-age adults (those with more than a high school education). In these specifications, the minimum wage effect on the employment rate of young persons is identified from changes in this rate relative to changes in the 
employment rate for skilled prime-age adults. ${ }^{11}$

One potential problem with this relatively standard approach to estimating minimum wage effects on employment is that in equations such as (1) and (2) the employment effect is averaged over many individuals, including a large fraction earning wages well above the minimum wage. For example, data from the 1995 CPS ORG files indicate that in 1995, 74.4 percent of workers aged 1624 earned a wage above $\$ 5.15$. Thus, minimum wage effects that may impact the lowest-skill teenagers and young adults may be obscured by a large proportion of higher-skill teenagers or young adults for whom minimum wages are not predicted to have any disemployment effect (and for whom, in fact, minimum wages may have positive employment effects, if higher minimum wages cause employers to substitute towards them). Of course, the minimum wage variables are constructed to account for the proportion of workers affected by the minimum wage. Nonetheless, if the minimum wage variables have no bearing on employment for many individuals in the sample, it may be difficult to detect employment effects of minimum wages even if they are present.

It is often thought that we can obtain some evidence on this question from a comparison of the results for teenagers and young adults, since teenagers have lower skills. However, given the possibility of employment and school enrollment interactions in response to minimum wage changes, this comparison may not be the best way to separate more-skilled from less-skilled individuals. Neumark and Wascher (1995) found that minimum wages increase the probability that some teenagers leave school to become employed or work more hours, and increase the probability that other teenagers become non-enrolled and non-employed. This evidence suggests that minimum

\footnotetext{
${ }^{11}$ It is still conceivable, however, that there are state-level differences in changes in employment of younger, unskilled workers. One way to control for this is to include lagged values of the dependent variable. However, this introduces correlation between regressors and residuals in panel data, and may not capture contemporaneous changes in state-level economic conditions as well as contemporaneous changes in employment of older, more-skilled workers. I therefore forego this analysis.
} 
wage increases shift demand to more-skilled teenagers, encouraging them to leave school, while simultaneously taking the places of the least-skilled teenagers who have already left school, causing them to become idle. ${ }^{12}$ Thus, the net employment effect of minimum wages for teenagers may be quite small, even though there are substantial gross disemployment effects on teenagers already out of school. On the other hand, for the broader 16-24 year-old group there may be less scope for a supply response, since a far greater proportion of this age group is employed, resulting in larger net disemployment effects. This is consistent with results reported in Neumark and Wascher (1992 and 1994b). For teens, negative effects of minimum wages on employment are apparent only conditioning on enrollment. But for young adults, the negative employment effects arise whether or not the enrollment rate is included as a control variable. ${ }^{13}$

I therefore propose a different approach to focusing on employment effects among those most likely to be affected by minimum wage increases. Specifically, equations (1) and (2) will be reestimated for a sample of non-enrolled individuals in the 16-24 age range, with a high school education or less. ${ }^{14}$ The non-enrolled will be identified using the independent enrollment measure available in the monthly CPS files. ${ }^{15}$ By isolating less-skilled workers, I expect to find stronger disemployment effects of minimum wages, if they are indeed present. This analysis will be done for the 16-24 year-old group rather than the 16-19 year-old group, since for teenagers employment and schooling outcomes are particularly likely to be jointly endogenous, making the sample selection rule strongly associated with the minimum wage variable for this narrow age group. Results will also be

${ }^{12}$ Micro-level evidence consistent with this is reported in Neumark and Wascher (1996a).

${ }^{13}$ These results are summarized in Table 1.

${ }^{14}$ I will also consider looking at a sample of the non-enrolled with less than a high school education, although the number of observations per state may be too small to obtain reliable estimates.

${ }^{15}$ There has been some debate regarding the best measure of the enrollment rate (see Card, et al., 1994; Neumark and Wascher, 1994b and 1996b; and Evans and Turner, 1995). 
reported for 20-24 year-olds, to attempt to verify that this endogenous selection does not drive the results.

The various empirical analyses described in this section to a large extent focus on specifications estimated in earlier work by Neumark and Wascher and by Card, as well as considering some enhancements of these specifications stemming from work by Deere, et al. By laying out a pre-specified research design, the reader is assured that the results reported in the following section do not reflect specification search that may be biased by prior expectations of results, precisely because no specification choices are made after looking at the data. At the same time, there may be other reasons why minimum wage effects are not the same over time, only some of which, perhaps, can be addressed via the variations in the specifications described in this section. Thus, in my view the evidence should be interpreted as removing one possible source of bias from estimates of minimum wage effects, but not necessarily as providing definitive estimates in light of which earlier work should be discounted. As is often the case in applied econometrics, removing one source of bias may exacerbate other sources of bias, and hence does not necessarily leave us with less biased estimates. ${ }^{16}$ In particular, because economic theory rarely provides us with the functional forms, lag structures, etc., that should be used in empirical work, careful specification analysis plays an important role. While the pre-specified research design approach should eliminate bias from specification search, it may also be prone to errors stemming from the absence of specification analysis. On the other hand, the pre-specified research design approach may be most useful in areas of inquiry--such as employment effects of minimum wages--in which researchers have in the past thought carefully, based on both theory and existing evidence, about the specifications to be estimated. In such areas, pre-specified designs are less likely to include severe specification errors

\footnotetext{
${ }^{16}$ Griliches (1977) makes this point in another context.
} 
that should be corrected based on examination of the data. With these provisos in mind, the next section reports the estimates.

\section{$\underline{\text { III. Results }}$}

This section describes the results that were computed after the pre-specified research design was "accepted/approved" by this journal, and, subsequent to that, the data were accessed and analyzed.

Results for All Teenagers and Young Adults

Results for teenagers are reported in Table 3. The table focuses on the specifications with fixed state and year effects. ${ }^{17}$ The columns differ in the minimum wage variables they use (relative minimum wages in columns (1) and (3), and the fraction below variable in columns (2) and (4)). They also differ with respect to the inclusion of the employment rate for skilled prime-age adults. As these estimates make clear, across all of the specifications there is no statistically significant effect of either minimum wage variable, whether current, lagged, or summed, on the employment rate of teenagers. The estimated effects are not precisely estimated, but are indeed near zero. In columns (1) and (3) this is easily seen in terms of the elasticity of employment of workers in this age group with respect to the minimum wage. In columns (2) and (4) the estimated coefficient is also relatively straightforward to interpret. For example, a coefficient of -.1 would imply that a minimum wage increase that sweeps up an additional ten percent of the teenage workforce would reduce the employment rate by .01 .

Below the basic specification, results from some alternatives are reported. First, estimates

\footnotetext{
${ }^{17}$ As discussed below, the data generally rejected restrictions to random state or year effects uncorrelated with the regressors.
} 
are reported when only the lagged minimum wage variable is used. ${ }^{18}$ The point estimates are still very small and insignificant. Next, the estimates are reported using data on state means only from the ORG files, for the specifications with contemporaneous and lagged and with only lagged minimum wage effects. Not surprisingly, because use of the ORG files entails throwing away considerable amounts of data (while perhaps imposing more consistency on the samples), the coefficient estimates are less precise, and if anything they are more positive for the relative minimum wage variable specifications.

Turning to some of the other coefficient estimates, there are a couple of anomalous results in Table 3 (which also appear below in most specifications in Table 4 for the broader 16-24 year-old age group). In particular, the estimated coefficients of the prime-age male unemployment rate are positive, and those of the employment rate of skilled prime-age adults negative. Although none of these are statistically significant, the signs of the estimates for both variables are contrary to expectations, and the results for the unemployment rate are at odds with what other research shows for longer panels (e.g., Neumark and Wascher, 1992). This suggests that, at least for some demographic groups, it may be difficult to tease out cyclical effects in the data using very short panels, over which movements in employment or unemployment rates of different age or skill groups may differ from longer-run relationships.

To summarize, the evidence for teenagers points to no net effects of minimum wages on employment. Looking back at Table 1, this is consistent with most of the existing research (Card, 1992a and 1992b, Neumark and Wascher, 1992 and 1994b), ${ }^{19}$ although inconsistent with Deere, et

\footnotetext{
${ }^{18}$ Although this particular restriction was not mentioned in Section II, in some of the subsequent tables the results point to negative, statistically significant lagged employment effects, and positive but insignificant contemporaneous effects, raising the possibility that the lagged effects would not be significant if considered in isolation. Estimates of the restricted model address this question.

${ }^{19}$ As already mentioned, Wascher and I only found significant effects on teenage employment after accounting for minimum wage effects on enrollment.
} 
al. (1995).

Table 4 turns to results for the broader 16-24 year-old young adult group. The structure of the table is identical to Table 3. For this broader age group the estimated effects of minimum wages reported in the top panel are again not statistically significant, although many of the coefficient estimates of the lagged minimum wage variables are negative with t-statistics larger than one. It is also worth noting that the estimated elasticities for young adults when using the relative minimum wage variable are around -.15 . Although perhaps coincidental, and certainly imprecisely estimated, these elasticities are within the "consensus" range of estimates often cited in the literature (e.g., Brown, et al., 1982), based on relative minimum wage specifications. ${ }^{20}$ The results are quite similar when only the lagged minimum wage variable is included. However, not surprisingly given their imprecision, these estimates are not robust, becoming positive (still insignificant) when only the ORG files are used, with the estimates again less precise.

Overall, then, some of the estimates in Table 4 are consistent with a negative effect of minimum wages on employment of 16-24 year-olds, with some of the point estimates of the disemployment effects (and to some extent the appearance of disemployment effects with a lag) consistent with earlier research. However, the estimates are very imprecise, and are not robust to the restriction to ORG files. The imprecision and perhaps the non-robustness of the evidence emphasizes the reservation expressed in the Introduction regarding the pre-specified research design approach to the study of minimum wage effects--namely, that because such an approach has to rely on relatively little data (unless one commits to the design a decade or more in advance), it may be difficult to draw strong conclusions of any kind, even when the point estimates are consistent with past research in which similar magnitudes were statistically significant.

\footnotetext{
${ }^{20}$ As Table 1 shows, my earlier work with Wascher tended to find elasticities in the range of -.15 to -.2 for this age group.
} 


\section{Results for Less-Skilled Young Workers}

Next, results are reported for subsamples of non-enrolled individuals with no more than a high school education. Recall that the expectation was that for these less-skilled workers, disemployment effects of minimum wages would be more apparent. The estimates in Table 5, for 16-24 year-olds, are consistent with these expectations.

For the specifications using either the relative minimum wage variable or the fraction below variable, there are large and statistically significant estimates (at the five- or ten-percent level) of lagged disemployment effects. ${ }^{21}$ The sum of the contemporaneous and lagged effects is significant at the ten-percent level for the fraction below specification, and very nearly so for the relative minimum wage specification (with p-values of .117 and .121). When the contemporaneous variable is dropped the estimated lagged effect remains large (scarcely changing) and significant at the five-percent level for the relative minimum wage specification, and fairly large and marginally significant for the fraction below specification. However, there is still some evidence of non-robustness; when we use data only from the ORGs, the estimated effects are still negative, but significant (at the ten-percent level) only when the fraction below version of the minimum wage variable is used. Overall, though, the results in this table point rather strongly to disemployment effects of recent increases in minimum wages on younger, less-skilled workers.

Table 6 restricts attention to 20-24 year-olds. Most of the estimates are in the same direction of indicating disemployment effects of minimum wages, but the statistical strength of the evidence is somewhat weaker. Nonetheless, there is some evidence of disemployment effects of minimum wages that is significant at the ten-percent level (using the relative minimum wage variable in the basic files) or marginally significant (using the fraction below variable for the ORG files). It is also

\footnotetext{
${ }^{21}$ When unspecified, statements regarding statistical significance refer to five-percent significance levels, and all statements refer to two-sided tests.
} 
of note that, unlike in the earlier tables, in Tables 5 and 6 the estimated effect of the prime-age male unemployment rate is negative (and significant in Table 5), consistent with earlier research, suggesting that for the subsamples considered in these tables the cyclical effects are probably extracted more reliably.

In general, then, the analysis of less-skilled workers, defined as those who are non-enrolled and have at most a high school education, yields stronger evidence of disemployment effects of minimum wages, although even here the estimates are sometimes imprecise or non-robust.

Finally, as mentioned in the pre-specified research design in Section II, a more severe sample restriction to those with less than a high school education was considered. As suspected, this led to rather imprecise estimates, as the samples became quite small. In particular, the estimated coefficients on the relative minimum wage variables were in the .61 to .77 range for the $16-24$ and 20-24 year-old subsamples, respectively, so obviously nothing useful could be learned. But the standard errors of the estimated coefficients of the fraction below variables did not go up as sharply, and therefore still permitted some conclusions to be reached.

The evidence for the fraction below specifications for these more restrictive subsamples are presented in Table 7. For 16-24 year-olds, there is quite robust evidence of disemployment effects of minimum wages, as significant negative estimates are obtained for the basic files and the ORG files, in the latter case whether or not the contemporaneous effect is dropped. The coefficient estimates are centered on approximately - .20 , implying that a minimum wage increase that sweeps up an additional ten percent of these workers reduces their employment rate by 2.0 percentage points. Since the average employment rate for this group is .518 , this represents a 3.9 percent drop in employment. For 20-24 year-olds, the evidence is in the same direction, but a little bit weaker statistically. Nonetheless, lagged disemployment effects that are significant at the ten-percent level appear for both the basic and ORG files. Thus, the results for those with less than a high school 
education, like the evidence for those with at most a high school education, provide reasonably strong evidence that recent minimum wage increases reduced employment of less-skilled workers below what would have otherwise occurred.

\section{Model Specification}

One other specification issue that was considered was whether fixed state and year effects need to be included, rather than random effects, which can yield more efficient estimates. The data nearly always rejected the restriction to random state effects, and more than half the time rejected the restriction to random year effects at the ten-percent level. ${ }^{22}$ This was especially true for the estimates using the subsamples excluding those with more than a high school education (Tables 5-7), where the data nearly always called for fixed state and fixed year effects. This implies that the significant negative effects of minimum wages on employment that were often found for these subsamples are based on the appropriate specification. ${ }^{23}$

Aside from this statistical evidence, it is clear that in this sample period, which witnessed a strong expansion and improving labor market conditions for less-skilled workers, it is essential to net out aggregate effects that may be correlated with minimum wage increases, in estimating the impact of minimum wages; so on a priori grounds, as well, fixed year effects are desirable.

\section{$\underline{\text { IV. Conclusion }}$}

This paper presents evidence on disemployment effects of minimum wages from a prespecified research design that entailed committing to a set of detailed statistical analyses prior to "going to" the data (enforced, in part, by specifying the research design prior to the release of the

\footnotetext{
${ }^{22}$ The Hausman tests were based on the "non-incidental" parameters, i.e., the estimated coefficients of the minimum wage variables, prime-age male unemployment rate, population share, and (when included) the employment rate of skilled prime-age adults.

${ }^{23}$ Most of the cases with p-values much higher than .1 (for the test regarding year effects) are in the specifications for all teenagers (Table 3), where there is no evidence of disemployment effects of minimum wages; for these specifications, the estimated elasticities were similar with random year effects.
} 
data). In this particular context, using a pre-specified research design entails a substantial cost in terms of lost data, because data that have previously been analyzed (i.e., earlier CPS files) must be omitted from the analysis. As a result of using relatively few years of data, over a period in which there is some--but limited--independent variation in minimum wages at the state level, some of the estimates obtained are quite imprecise, limiting the ability to draw firm conclusions. On the other hand, the potential gain from pre-specified research designs is the avoidance of biased specification search, by eliminating any specification search. To the extent that this goal can be achieved, prespecified research designs are worth pursuing, especially in areas where there appear to be author effects in the published evidence. While I think the jury is likely to remain out on the feasibility or value of using pre-specified research designs in empirical economics, the minimum wage debate is a natural application, and I commend this journal for attempting to elicit papers using such designs from participants in this debate.

Turning to the results of implementing the pre-specified research design, evidence of disemployment effects of minimum wages is often found where we would most expect it--for younger, less-skilled workers (i.e., those with low education levels). In addition, some of the other evidence is qualitatively consistent with findings in earlier research that I and others have done using standard empirical analysis (i.e., not a pre-specified design), including: no evidence of disemployment effects for teenagers as a whole; employment elasticities of - .1 to - .2 for 16-24 year-olds; and disemployment effects generally occurring with a lag.

Thus, findings consistent with the predictions of a standard labor market model, and with past empirical research indicating disemployment effects of minimum wages, emerge from an empirical approach that should be immune from any author effects. However, in some cases the limitations on the data available for the pre-specified design, and the consequent imprecision of the estimates, makes it difficult to rule out a fairly wide range of hypotheses. At least in the context of 
this particular debate, this suggests that although pre-specified research designs may be a valuable empirical tool, more traditional means of disentangling conflicting evidence--including careful scrutiny of published evidence by other researchers--are likely to remain important. 


\section{$\underline{\text { References }}$}

Baker, Michael, Dwayne Benjamin, and Shuchita Stanger. 1999. "The Highs and Lows of the Minimum Wage Effect: A Time-Series Cross-Section Study of the Canadian Law." Journal of Labor Economics, Vol. 17, No. 2, April, pp. 318-50.

Brown, Charles, Curtis Gilroy, and Andrew Kohen. 1982. "The Effect of the Minimum Wage on Employment and Unemployment." Journal of Economic Literature, Vol. 20, No. 2, June, pp. 487-528.

Card, David. 1992a. "Using Regional Variation in Wages to Measure the Effects of the Federal Minimum Wage." Industrial and Labor Relations Review, Vol. 46, No. 1, October, pp. 22 37.

. 1992b. "Do Minimum Wages Reduce Employment? A Case Study of California, 19871989." Industrial and Labor Relations Review, Vol. 46, No. 1, October, pp. 38-54.

Card, David, Lawrence F. Katz, and Alan B. Krueger. 1994. "Comment on David Neumark and William Wascher, "Employment Effects of Minimum and Subminimum Wages: Panel Data on State Minimum Wage Laws"." Industrial and Labor Relations Review, Vol. 47, No. 3, April, pp. 487-96.

Card, David, and Alan B. Krueger. 1994. "Minimum Wages and Employment: A Case Study of the Fast-Food Industry in New Jersey and Pennsylvania." American Economic Review, Vol. 84, No. 4, September, pp. 772-793.

. 1995. "Time-Series Minimum-Wage Studies: A Meta-Analysis." American Economic Review Papers and Proceedings, Vol. 85, No. 2, May, pp. 238-43.

Currie, Janet, and Bruce C. Fallick. 1996. "The Minimum Wage and the Employment of Youth: Evidence from the NLSY." Journal of Human Resources, Vol. 21, No. 2, Spring, pp. 404428.

Deere, Donald, Kevin M. Murphy, and Finis Welch. 1995. "Employment and the 1990-1991 Minimum-Wage Hike." American Economic Review Papers and Proceedings, Vol. 85, No. 2, May, pp. 232-7.

Evans, William N., and Mark Turner. 1995. "Employment Effects of Minimum and Subminimum Wages: Comment." Mimeograph, University of Maryland.

Griliches, Zvi. 1977. "Estimating the Returns to Schooling: Some Econometric Problems." Econometrica, Vol. 45, No. 1, January, pp. 1-22.

Katz, Lawrence F., and Alan B. Krueger. 1992. "The Effect of the Minimum Wage on the Fast-Food Industry." Industrial and Labor Relations Review, Vol. 46, No. 1, October, pp. 6-21.

Kim, Taeil, and Lowell J. Taylor. 1995. "The Employment Effect in Retail Trade of California's 1988 Minimum Wage Increase." Journal of Business and Economic Statistics, Vol. 13, 
Neumark, David, and William Wascher. 1992. "Employment Effects of Minimum and Subminimum Wages: Panel Data on State Minimum Wage Laws." Industrial and Labor Relations Review, Vol. 46, No. 1, September, pp. 55-81.

. 1994a. "Minimum Wage Effects and Low-Wage Labor Markets: A Disequilibrium Approach." NBER Working Paper No. 4617.

. 1994b. "Employment Effects of Minimum and Subminimum Wages: Reply to Card, Katz, and Krueger." Industrial and Labor Relations Review, Vol. 47, No. 3, April, pp. 497-512.

1995. "Minimum Wage Effects on Employment and School Enrollment." Journal of Business and Economic Statistics, Vol. 13, No. 2, April, pp. 199-206.

. 1996a. "The Effects of Minimum Wages on Teenage Employment and Enrollment:

Estimates from Matched CPS Data.” Research in Labor Economics, Vol. 15, pp. 25-64.

Federal Reserve Board.

1996b. "Reply to Evans and Turner." Finance and Economics Discussion Series No. Z.11, . 1998a. "The New Jersey-Pennsylvania Minimum Wage Experiment: A Re-Evaluation Using Payroll Records." Mimeograph, Michigan State University.

1998b. "Is the Time-Series Evidence on Minimum Wage Effects Contaminated by Publication Bias?" Economic Inquiry, Vol. 36, No. 3, July, pp. 458-70.

$</$ ref_section $>$ 
Table 1

Elasticities of Employment with Respect to the Minimum Wage from Recent Studies

$\underline{\text { Study }}$

Card and Krueger (1994)

Card (1992a)

Card (1992b)

Katz and Krueger (1992)

Neumark and Wascher (1992, 1994b)

Card, Katz, and Krueger (1994)

Kim and Taylor (1995)

Deere, Murphy, and Welch

(1995)

Currie and Fallick (1996)

Neumark and Wascher (1998a)

\section{Data source}

Survey of fast-food restaurants in $\mathrm{NJ}$ and $\mathrm{PA}$

1989-1990 CPS Outgoing

Rotation Group files, April-December

1987-1989 CPS Outgoing

Rotation Group files, for CA and five states or cities as comparison groups

Survey of fast-food restaurants in TX

May CPS files, 1973-1989

Data from Neumark and Wascher (1992)

County Business Patterns, March 1988-March 1989, CA and rest of U.S.

CPS Outgoing Rotation Group Files, 1985-1993

\section{NLSY}

Resurvey of fast-food restaurants in NJ and PA $\frac{\text { Workers studied }}{\text { Fast-food workers }}$

$\underline{\text { Elasticities }}$ $.61(*), .69(* *)^{\mathrm{a}}$

Teenagers

$\sim 0^{\mathrm{b}}$

Teenagers

$.47(* *)^{\mathrm{c}}$

Fast-food workers

$1.70(*), 1.85(*)^{\mathrm{d}}$

Teenagers, young adults aged 16-24

Teenagers

Retail-trade workers

Teenagers (15-19)

Youths

Fast-food workers
$<0(* *)^{\mathrm{g}}$

-.27 (males), $-.42(* *)$ (females), $-.37(* *)(\text { blacks })^{\mathrm{h}}$ $-.09(* *)^{\mathrm{i}}$

$\sim 0$ (teenagers, without enrollment control), -.1 to $-.2(*)$ (teenagers, with enrollment control), -.15 to $-.2(* *)$ (young adults, with or without enrollment control) ${ }^{\mathrm{e}}$

$.37(* *)^{\mathrm{f}}$

-.1 to $-.3(* *)^{\mathrm{j}}$

A double asterisk indicates statistical significance at the five-percent level, and a single asterisk at the ten-percent level.

a. First estimate is from Table 4, row (1), column (1). Second estimate is from Table 5, row (9), column (3).

b. Estimates come from Table 4, columns (1)-(4). Paper uses "fraction affected" as minimum wage variable, so a comparable elasticity cannot be calculated.

c. Estimate is calculated from row (9) of Table 4.

d. Estimates are from Table 5, columns (1) and (2), reported on p. 15.

e. Estimates are from Tables 5-6, reported on p. 78. Estimates for teens with enrollment control are sometimes statistically significant at the five-percent level, and sometimes insignificant, so a single asterisk is reported.

f. Estimate is from Table 1, column (3), using the mean teen employment rate of .43 to compute an elasticity.

g. The authors estimate a labor demand elasticity, using the minimum wage increase as an instrument for changes in wages. No minimum wage elasticity is reported.

h. Estimates are from Table 4, reported on p. 235.

i. The authors report a three-percent decline in the probability of employment for those bound by the minimum wage increase (p. 410). The average minimum wage increase was 7.5 percent, and an average of 21.5 percent were bound, so (3/7.5) .215 is reported. j. Estimates are from Tables 4 and 6. Estimates are sometimes statistically significant at the five-percent level, and sometimes insignificant, so a single asterisk is reported. 
Table 2

State and Federal Minimum Wages

\begin{tabular}{|c|c|c|c|c|c|c|c|c|c|}
\hline & \multicolumn{5}{|c|}{ Higher of state or federal minimum wage, October } & \multicolumn{4}{|c|}{ Minimum wage change, October to October } \\
\hline & 1994 & 1995 & 1996 & 1997 & 1998 & $1994-1995$ & 1995-1996 & 1996-1997 & $1997-1998$ \\
\hline Alaska & 4.75 & 4.75 & 5.25 & 5.65 & 5.65 & 0 & .50 & .40 & 0 \\
\hline California & 4.25 & 4.25 & 4.75 & 5.15 & 5.75 & 0 & .50 & .40 & .60 \\
\hline Connecticut & 4.27 & 4.27 & 4.77 & 5.18 & 5.18 & 0 & .50 & .40 & 0 \\
\hline D.C. & 5.25 & 5.25 & 5.75 & 6.15 & 6.15 & 0 & .50 & .40 & 0 \\
\hline Hawaii & 5.25 & 5.25 & 5.25 & 5.25 & 5.25 & 0 & $\underline{\mathbf{0}}$ & $\underline{\mathbf{0}}$ & 0 \\
\hline Iowa & 4.65 & 4.65 & 4.75 & 5.15 & 5.15 & 0 &.$\overline{10}$ &.$\overline{40}$ & 0 \\
\hline Massachusetts & 4.25 & 4.25 & 4.75 & 5.25 & 5.25 & 0 & $\overline{.50}$ & .50 & 0 \\
\hline New Jersey & 5.05 & 5.05 & 5.05 & 5.15 & 5.15 & 0 & $\underline{\mathbf{0}}$ & .10 & 0 \\
\hline Oregon & 4.75 & 4.75 & 4.75 & 5.50 & 6.00 & 0 & $\underline{\mathbf{0}}$ & .75 & .50 \\
\hline Rhode Island & 4.45 & 4.45 & 4.75 & 5.15 & 5.15 & 0 &.$\overline{\mathbf{3 0}}$ & $\overline{.40}$ & $\overline{0}$ \\
\hline Vermont & 4.25 & 4.50 & 4.75 & 5.25 & 5.25 & .25 & .25 & .50 & 0 \\
\hline Washington & 4.90 & 4.90 & 4.90 & 5.15 & 5.15 & 0 & $\underline{\mathbf{0}}$ & .25 & 0 \\
\hline $\begin{array}{l}\text { Other states (federal } \\
\text { minimum prevails } \\
\text { in all five years) }\end{array}$ & 4.25 & 4.25 & 4.75 & 5.15 & 5.15 & 0 & .50 & .40 & 0 \\
\hline
\end{tabular}

Minimum wages are shown for any state with a minimum wage exceeding the federal minimum over this period. In all cases, minimum wages are those prevailing as of October 1 of each year. In the four right-hand columns, the increases that differ from the federal increases are highlighted. 
Table 3

Estimated Effects of Minimum Wages on Employment of 16-19 Year-Olds

Fixed state and year effects,

basic files:

Relative minimum wage

Relative minimum wage,

lagged one year

Elasticity

Fraction below

Fraction below,

lagged one year

Prime-age male

unemployment rate

Population share

Employment rate of

skilled prime-age adults

Sum of coefficients of

minimum wage variables

Test of significance of sum of

minimum wage variables ( $p$-values)

Specification with lagged

minimum wage variable only:

Relative minimum wage/

fraction below

Data from ORG files only:

Sum of coefficients of

minimum wage variables

Test of significance of sum of

minimum wage variables ( $\mathrm{p}$-values)

Lagged minimum wage

variable only
(2)

(4)

.098

(.241)

$\begin{array}{ll}\ldots & .099\end{array}$

(.241)

$\begin{array}{lll}-.025 & \ldots & -.015 \\ (.246) & & (.247)\end{array}$

.064

$\ldots$

.073

$\cdots$

.014

.012
$\quad(.028)$

$(.028)$

$\begin{array}{ll}\cdots & -.014 \\ - & (.030)\end{array}$

$\begin{array}{ll}\ldots & -.013\end{array}$

(.030)

(.030)

.273

.338

(.475)

.057

(.552)

.116

(.471)

$-.348$

$-.373$

(.553)

$-.369$

(.399)

(.414)

$-.352$

(.400)

$\begin{array}{llll}\ldots & \ldots & -.524 & -.543 \\ & & & (.694)\end{array}$

.073

$-.002$

.084

.001

.813

.973

.787

.993

$-.006$

$-.016$

.005

(.242)

$-.016$

(.241)

(.029)

(.030)

.316

.008

.312

.008

.443

.889

.452

.898

.062

.005

.058

(.327)

.005

(.039)

All variables are state means constructed using sample weights. The elasticity is computed using the sum of the current and lagged minimum wage effects, evaluated at sample means. See Appendix Table A1 for variable definitions and descriptive statistics. For the minimum wage variables, a double asterisk indicates statistical significance at the five-percent level, and a single asterisk at the ten-percent level. There are 204 observations. 
Table 4

Estimated Effects of Minimum Wages on Employment of 16-24 Year-Olds

Fixed state and year effects,

(2)

(3)

(4)

basic files:

Relative minimum wage

$\begin{array}{lll}-.001 & \ldots & -.002 \\ (.168) & & (.169)\end{array}$

Relative minimum wage,

$\begin{array}{lll}-.217 & \ldots & -.213\end{array}$

lagged one year

$(.171)$

$(.172)$

Elasticity

$-.145$

$\ldots$

$-.143$

Fraction below

$\ldots$

.021

$\ldots$
.025

(.035)

(.036)

Fraction below,

lagged one year

$\begin{array}{ll}\cdots & -.038 \\ & (.038)\end{array}$

$\begin{array}{ll}\ldots & -.041\end{array}$

$(.038)$

(.038)

Prime-age male

$\begin{array}{lccc}.096 & .131 & .007 & -.014 \\ (.329) & (.329) & (.386) & (.385)\end{array}$

Population share

$\begin{array}{lccc}.330 & .334 & .334 & .341 \\ (.194) & (.187) & (.195) & (.187)\end{array}$

Employment rate of skilled prime-age adults

$\begin{array}{llll}\ldots & \ldots & -.217 & -.361 \\ & & (.486) & (.492)\end{array}$

Sum of coefficients of minimum wage variables

$\begin{array}{llll}-.218 & -.017 & -.215 & -.016\end{array}$

Test of significance sum of minimum wage variables (p-values)

Specification with lagged

minimum wage variable only:

Relative minimum wage/

$-.218 \quad-.041$

$-.213$

$-.043$

fraction below

(.168)

(.038)

(.169)

(.038)

Data from ORG files only:

Sum of coefficients of minimum wage variables

$\begin{array}{llll}.144 & .029 & .148 & .030\end{array}$

Test of significance of sum of minimum wage variables (p-values)

.667

.727

Lagged minimum wage

$\begin{array}{llll}.076 & .004 & .080 & .004\end{array}$

variable only

(.263)

(.059) (.267)

(.059)

See notes to Table 3. There are 204 observations. 
Table 5

Estimated Effects of Minimum Wages on Employment of Non-Enrolled 16-24 Year-Olds with No More than High School Education

Fixed state and year effect,

(2)

basic files:

Relative minimum wage

.192

$\begin{array}{ll}\ldots & .191\end{array}$

$-726 *$

$(.263)$

Relative minimum wage,

$-.726^{* *}$

$-.722^{* *}$

lagged one year

(.268)

(.269)

Elasticity

$-.308$

$\ldots$

$-.306$

Fraction below

$\cdots$

$-.038$

$\begin{array}{ll}\ldots & -.037\end{array}$

(.046)

(.046)

Fraction below,

lagged one year

... $\quad-.076^{*}$

$(.046)$

$\begin{array}{ll}\ldots & -.076^{*}\end{array}$

(.046)

Prime-age male

$\begin{array}{llll}-1.190 & -1.145 & -1.280 & -1.264\end{array}$

unemployment rate

(.513)

(.520)

(.602)

(.609)

Population share

$\begin{array}{llll}-.016 & -.000 & -.012 & .005\end{array}$

(.302)

(.295)

(.304)

(.297)

Employment rate of

skilled prime-age adults

$\begin{array}{llll}\ldots & \ldots & -.219 & -.288\end{array}$

(.758) (.769)

Sum of coefficients of

minimum wage variables

$\begin{array}{llll}-.534 & -.114^{*} & -.531 & -.113^{*}\end{array}$

Test of significance of sum of

minimum wage variables (p-values)

.117

.094

.121

.099

Specification with lagged

minimum wage variable only:

Relative minimum wage/

$-.691$

$-.073$

$-.686^{* *}$

$-.073$

(.263)

(.046)

$(.264)$

(.046)

Data from ORG files only:

Sum of coefficients of

minimum wage variables

$\begin{array}{llll}-.179 & -.194^{*} & -.075 & -.171^{*}\end{array}$

Test of significance of sum of

minimum wage variables ( $\mathrm{p}$-values)

$\begin{array}{llll}.741 & .063 & .889 & .099\end{array}$

Lagged minimum wage

$\begin{array}{llll}-.256 & -.112 & -.132 & -.096 \\ (.418) & (.071) & (.417) & (.071)\end{array}$

variable only

$(.418)$

$(.071)$

$(.417)$

$(.071)$

See notes to Table 3. Non-enrollment is based on the independent enrollment measure in the CPS. The population share variable is defined without reference to education. There are 204 observations. 
Table 6

Estimated Effects of Minimum Wages on Employment of Non-Enrolled 20-24 Year-Olds with No More than High School Education

Fixed state and year effects,

(2)

(3)

(4)

basic files:

Relative minimum wage

$\begin{array}{lll}.306 & \ldots & .307\end{array}$

(.282) $(.283)$

Relative minimum wage,

$\begin{array}{lll}-.567^{*} & \ldots & -.571^{*}\end{array}$

lagged one year

Elasticity

$-.143$

$\ldots$

$-.145$

Fraction below

$\begin{array}{lll}-.030 & \ldots & -.031 \\ (.049) & & (.049)\end{array}$

Fraction below,

lagged one year

$\begin{array}{lccc}\ldots & -.059 & \ldots & -.059 \\ & (.047) & & (.048)\end{array}$

Prime-age male

$\begin{array}{llll}-.910 & -.835 & -.837 & -.811\end{array}$

unemployment rate

$(.571)$

(.575)

(.670)

(.677)

Population share

$\begin{array}{llll}-.737 & -.769 & -.743 & -.771 \\ (.418) & (.421) & (.421) & (.424)\end{array}$

Employment rate of skilled prime-age adults

$\begin{array}{llll}\ldots & \ldots & .177 & .059\end{array}$$$
\text { .. }
$$

Sum of coefficients of

minimum wage variables

$\begin{array}{llll}-.261 & -.089 & -.264 & -.090\end{array}$

Test of significance of sum of

minimum wage variables (p-values)

$.484 \quad .222$

.481

.224

Specification with lagged

minimum wage variable only:

Relative minimum wage/

$\begin{array}{llll}-.511^{*} & -.054 & -.514^{*} & -.054 \\ (.293) & (.047) & (.294) & (.047)\end{array}$

Data from ORG files only:

Sum of coefficients of

minimum wage variables

.31

$-.06$

.393

$-.053$

Test of significance of sum of minimum wage variables ( $\mathrm{p}$-values)

$\begin{array}{cccc}.601 & .573 & .513 & .636 \\ & & & \\ .032 & -.114 & .160 & -.111 \\ . .470) & (.073) & (.470) & (.072)\end{array}$

Lagged minimum wage

(.470)

(.073)

(.470)

$(.072)$

See notes to Tables 3 and 5. There are 204 observations. 
Table 7

Estimated Effects of Minimum Wages on Employment of Non-Enrolled 16-24 and 20-24 Year-Olds with Less than High School Education

Fixed state and year effects,

16-24 year-olds

basic files:

Fraction below

Fraction below,

lagged one year

Prime-age male

unemployment rate

Population share

Employment rate of

skilled prime-age adults

Sum of coefficients of

minimum wage variables

Test of significance of sum of minimum wage variables (p-values)

$\mathrm{N}$

Specification with lagged

minimum wage variable only:

Fraction below

$\mathrm{N}$

Data from ORG files only:

Sum of coefficients of minimum wage variables

Test of significance of sum of minimum wage variables ( $p$-values)

$\mathrm{N}$

Lagged minimum wage

variable only

$\mathrm{N}$
(1)

(2)

$\begin{array}{ll}-.143^{* *} & -.136^{* *} \\ (.046) & (.046)\end{array}$

$-.013$

(.057)

$(.057)$

$\begin{array}{llll}-.070 & -.072 & -.104^{*} & -.107^{*} \\ (.050) & (.050) & (.055) & (.055)\end{array}$

(.050)

(.050)

(.055)

(.055)

$-1.839$

$-2.875$

(1.375)

$-1.625$

(1.415)

$-2.464$

(1.177)

$-.832$

$-2.931$

(1.006)

$-2.811$

$(.685)$

(.684)

...

$-2.157$

$-2.482$

(1.719)

$-.213^{* *}$

$-.208^{* *}$

$-.117$

$-.112$

.004

.005

.176

.193

203

203

187

187

$\begin{array}{llll}-.043 & -.046 & -.045 & -.056 \\ (.050) & (.050) & (.058) & (.058)\end{array}$

204

204

197

197

$\begin{array}{llll}-.338^{* *} & -.307^{* *} & -.010 & -.003\end{array}$

.002

.005

.943

.984

203

203

186

186

$\begin{array}{llll}-.191^{* *} & -.188^{* *} & -.176^{*} & -.175^{*} \\ (.073) & (.072) & (.091) & (.091)\end{array}$

(.073)

(.091)

(.091)

204

204

195

195

See notes to Tables 3 and 5. Because of a small number of empty cells for computing the fraction below variable (and the employment rate for the ORG files), sample sizes are sometimes slightly smaller in this table, as indicated. 


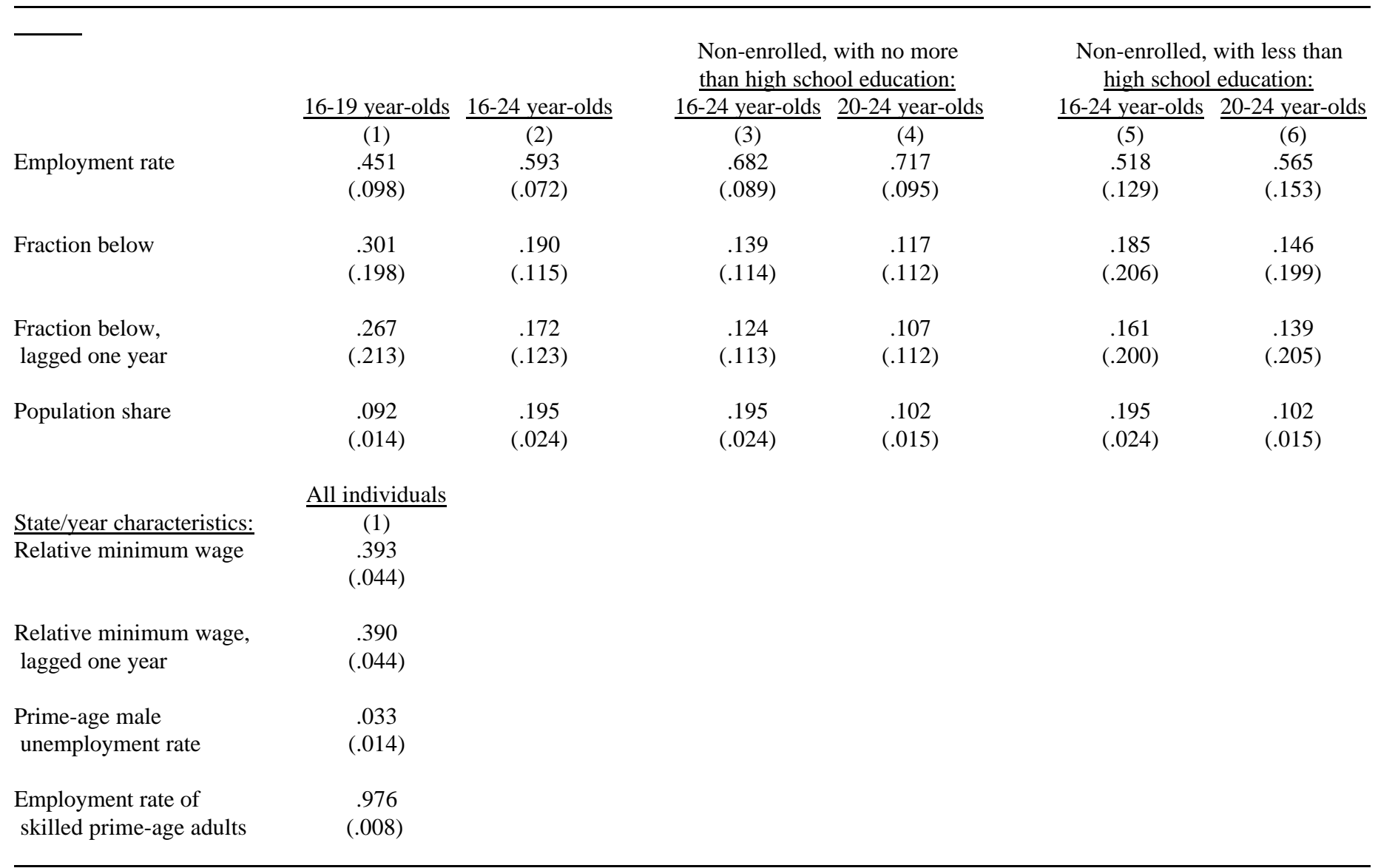

Table reports simple means across states and years of means for state-year cells, the latter of which are constructed using sample weights. Descriptive statistics are reported for monthly basic files only. Standard deviations are reported in parentheses. Population share is defined without reference to education, and relative to the number of 16-64 year-olds. The prime-age male unemployment rate covers ages 25 64 , and the employment rate for skilled prime-age adults is defined for 25-64 year-olds with more than a high school education. There are 204 observations, except in columns (5) and (6) where there are somewhat fewer because of a small number of empty cells for computing the fraction below variable (and the employment rate for the ORG files); see notes to Table 7. 
P-values from Hausman tests-don't include, unnecessary

Table 3

$\begin{array}{lllll}\text { No state effects } & 0.000 & 0.000 & 0.000 & 0.000\end{array}$

No year effects $\quad 0.698$

$\begin{array}{lll}0.580 & 0.815 & 0.692\end{array}$

Table 4

No state effects $\quad 0.000$

0.000

$0.000 \quad 0.982$

No year effects $\quad 0.270$

0.101

0.000

0.001

Table 5

No state effects $\quad 0.000$

0.000

0.003

$0.000 \quad 0.000$
0.007

No year effects $\quad 0.003$

0.007

0.001

Table 6

No state effects $\quad 0.000$

No year effects $\quad 0.007$

0.000

0.000

0.000

0.016

0.000

Table 7

No state effects $\quad 0.049$

0.002

0.143

0.042

0.398

0.041

No year effects

0.100

0.459 